\title{
PERSEPSI GURU MENGENAI SEX EDUCATION DI SEKOLAH DASAR KELAS VI
}

\section{Regina Lichteria Panjaitan',Dadan Djuanda ${ }^{2} \&$ Nurdinah Hanifah ${ }^{3}$}

\author{
1,2,3PGSD UPI Kampus Sumedang \\ 1,2,3 Jl. Mayor Abdurachman No. 211 Sumedang \\ 'Email: regina@upi.edu \\ 2Email: dadanpgsd@gmail.com \\ 3Email: nurdinah.hanifah@upi.edu
}

\begin{tabular}{|c|c|}
\hline ABSTRACT & ABSTRAK \\
\hline $\begin{array}{l}\text { The role of technology, especially information } \\
\text { technology in Indonesia in building society XXI } \\
\text { century. Indonesia has begun to enter the } \\
\text { stage of the telematics community will certainly } \\
\text { have a major impact on all levels of life of the } \\
\text { Indonesian nation, especially in children. The } \\
\text { emergence of a great revolution to the world of } \\
\text { children's playground, internet presence } \\
\text { replaces the open airy space for children's play, } \\
\text { besides presenting impressions internet } \\
\text { pornography and violence can harm the } \\
\text { development of children's personality. sexual } \\
\text { deviance behavior at the level of schooling is } \\
\text { quite surprising, of course, this is a challenge for } \\
\text { education and should be used as a rationale } \\
\text { for the need for innovation in learning. Things } \\
\text { into consideration is for this, sex education for } \\
\text { early childhood is considered taboo in society. } \\
\text { Guru is one of the determining factors of high } \\
\text { and low quality of education has a strategic } \\
\text { position in transforming sex education to } \\
\text { learners therefore this study tries to analyze how } \\
\text { perceptions of teachers on sex education at } \\
\text { primary school level, the research method used } \\
\text { is descriptive method. }\end{array}$ & $\begin{array}{l}\text { Peranan teknologi, khususnya teknologi informasi } \\
\text { di dalam membangun masyarakat Indonesia } \\
\text { abad XXI. Indonesia sudah mulai masuk pada } \\
\text { tahapan masyarakat telematika tentunya akan } \\
\text { berdampak besar pada seluruh aras kehidupan } \\
\text { bangsa Indonesia terutama pada anak-anak. } \\
\text { Munculnya revolusi besar terhadap dunia bermain } \\
\text { anak, kehadiran internet menggantikan ruang } \\
\text { lapang terbuka untuk bermain anak, selain itu } \\
\text { internet menghadirkan tayangan yang berbau } \\
\text { pornografi serta kekerasan yang bisa merugikan } \\
\text { perkembangan kepribadian anak-anak, yang } \\
\text { mengarahkan perilaku seksual anak. Prilaku } \\
\text { penyimpangan seksual di tingkat persekolahan } \\
\text { cukup mengejutkan, tentunya ini merupakan } \\
\text { tantangan bagi dunia pendidikan dan perlu } \\
\text { dijadikan dasar pemikiran bagi perlunya } \\
\text { pembaharuan dalam pembelajaran. Hal yang } \\
\text { menjadi bahan pertimbangan adalah selama ini, } \\
\text { pendidikan seks untuk anak usia dini dianggap } \\
\text { tabu di kalangan masyarakat. Guru merupakan } \\
\text { salah satu faktor penentu tinggi rendahnya mutu } \\
\text { hasil pendidikan mempunyai posisi strategis dalam } \\
\text { mentransformasikan sex education pada peserta } \\
\text { didik oleh karena itu penelitian ini mencoba untuk } \\
\text { menganalisis bagaimana persepsi guru terhadap } \\
\text { sex education di tingkat sekolah dasar, metode } \\
\text { penelitian yang digunakan adalah metode } \\
\text { deskriptif. } \\
\text { Kata kunci: Persepsi guru, sex education, peserta } \\
\text { didik di sekolah dasar. }\end{array}$ \\
\hline
\end{tabular}

How to Cite: Panjaitan, R., Djuanda, D., \& Hanifah, N. (2015). PERSEPSI GURU MENGENAI SEX EDUCATION DI SEKOLAH DASAR KELAS VI. Mimbar Sekolah Dasar, 2(2), 224-233. doi:http://dx.doi.org/10.17509/mimbar-sd.v2i2.1332.

PENDAHULUAN Pembangunan sebagai bagian dari perubahan dan transformasi sosial budaya ternyata melahirkan dampakseperti melemahnya nilai-nilai lama yang telah memperkuat struktur masyarakat sementara itu, nilai-nilai baru belum muncul, sehingga akan menimbulkan kesenjangan. Seperti yang diuraikan oleh Al-Muchtar, (2011, p. 225) bahwa. 
Regina L. Panjaitan, Dadan Djuanda, dan Nurdinah Hanifah, Persepsi Guru Mengenai Sex Edu...

... perubahan dan transformasi sosial budaya melahirkan ekses yang memerlukan perhatian serius, antara lain melemahnya nilai-nilai lama yang telah memperkuat struktur masyarakat. Sementara itu, nilai-nilai baru yang dibutuhkan belum muncul, sehingga akan menimbulkan kesenjangan budaya antara format perubahan sosial budaya dengan nilai-nilai baru yang relevan.

Gejala yang muncul dalam masyarakat kita sekarang yang sangat memprihatinkan berbagai kalangan, antara lain, melemahnya moral, solidaritas sosial, meningkatnya individualistik, kenakalan remaja, perlakuan penyimpangan seksual, merupakan gejala - gejala yang dapat menimbulkan masalah sosial.

Indonesia menyadari sepenuhnya betapa besar peranan teknologi khususnya teknologi informasi di dalam mebangun masyarat Indonesia pada abad XXI. Melalui instruksi presiden No. 6 Tahun 2001 tentang pengembangan dan pendayagunaan Telematika di Indonesia, menyiratkan adanya tujuan untuk membangun masyarakat Indonesia dengan pendayagunaan telematika. Tilaar (2012, p. 452) menggaris bawahi bahwa "bagi dunia pendidikan memanfaatkan teknologi merupakan hal yang penting dalam proses pengembangan warganegara yang intellegen" walaupun tidak bisa dipungkiri akan muncul dampak lainyang berpengaruh besar pada seluruh aras kehidupan bangsa Indonesia terutama pada anak-anak.

Degradasi nilai-nilai,demoralisasi dan dehumanisasi di era globalisasi informasi ini nampaknya memang sulit dibendung. Khususnya mengenai perlakukan penyimpangan seksual Pemberitaan media massa akhir-akhir ini cukup mengejutkan, sejumlah peserta didik sekolah Taman Kanak-kanak (TK) di Jakarta telah menjadi korban kekerasan dan pelecehan seksual. Terbongkarnya kasus tersebut bermula dari kecurigaan orang tua yang melihat adanya perubahan sikap anaknya, murung, takut ke sekolah dan tidak ceria lagi.Kasus tersebut telah mencoreng wajah pendidikan nasional, serta merendahkan harkat dan martabat bangsa Indonesia.Beberapa data mencatat mengenai asus pelecehan anak di Indonesia telah berulang kali terjadi, diantaranya Komisi Perlindungan Anak Indonesia (Komnas PA) mencatat kasus pelecehan seksual sepanjang tahun 2013 sebanyak 3.039 kasus, atau naik sekitar $87 \%$ dari tahun 2012. Salah satu kasus menghebohkan terjadi di salah satu sekolah menengah negeri di Jakarta Timur, pelakunya adalah seorang wakil kepala sekolah.Di tahun sebelumnya, telah terjadi kasus pelecehan seksual menimpa beberapa orang siswi yang dilakukan oleh Kepala Sekolah di Kalimantan Tengah. Sebagai catatan tambahan dari Komnas PA telah menghimpun data pada tahun 2012, menerima laporan kekerasan terhadap anak dari masyarakat sebanyak 2.637 kasus, dengan rincian $62 \%$ kasus kejahatan seksual, dan 38\% kekerasan fisik. Pada umumnya, kasus pelecehan tersebut dilakukan oleh orang-orang dekat korban, baik paman, orang tua, guru, teman, 
penjaga, petugas kebersihan sekolah dan lain sebagainya. (BIN,2014). Selanjutnya data tambahan berdasarkan data KPAl, pada Januari hingga Mei 2014, pengaduan kekerasan seksual terhadap anak mencapai lebih dari 400 advan.Padahal sepanjang 2013 hanya ada 502 advan anak berhadapan dengan hukum ( $A B H)$ untuk kasus kekerasan seksual.(KPAl, 2014).

Anak adalah generasi penerus bangsa dan penerus pembangunan, yaitu generasi yang dipersiapkan sebagai subjek pelaksana pembangunan yangberkelanjutan dan pemegang kendali masa depan suatu negara, tidakterkecuali Indonesia. Perlindungan anak Indonesia berarti melindungi potensisumber daya insani dan membangun manusia Indonesia seutuhnya, menujumasyarakat yang adil dan makmur, materiil spiritual berdasarkan Pancasiladan Undang-Undang Dasar 1945. Pasal 1 butir 2 Undang-Undang Nomor 23 Tahun 2002 tentang PerlindunganAnak, mengisyaratkan pelecehan seksual terhadap anak perlu mendapatkan perhatian seriusmengingat akibat dari kekerasan seksual terhadap anak akan menyebabkananak mengalami trauma yang berkepanjangan.Tentunya ini merupakan tantangan bagi dunia pendidikan dan perlu dijadikan dasar pemikiran bagi perlunya pembaharuan dalam pembelajaran.

Pendidikan seks usia dini dapat memberikan pemahaman anak akan kondisi tubuhnya, pemahaman akan lawan jenisnya, dan pemahaman untuk menghindarkan dari kekerasan seksual. Pendidikan seks yang dimaksud di sini adalah anak mulai mengenal akan identitas diri dan keluarga, mengenal anggota-anggota tubuh mereka, serta dapat menyebutkan ciri-ciri tubuh. Pemahaman pendidikan seks di usia dini ini diharapkan anak agar anak dapat memperoleh informasi yang tepat mengenai seks. Hal ini dikarenakan adanya media lain yang dapat mengajari anak mengenai pendidikan seks ini, yaitu media informasi. Sehingga anak dapat memperoleh informasi yang tidak tepat dari media massa terutama tayangan televisi yang kurang mendidik.

Dengan mengajarkan pendidikan seks pada anak, diharapkan dapat menghindarkan anak dari risiko negatif perilaku seksual maupun perilaku menyimpang. Dengan sendirinya anak diharapkan akan tahu mengenai seksualitas dan akibat-akibatnya bila dilakukan tanpa mematuhi. Pendidikan seks diperlukan untuk menjembatani antara rasa keingintahuan anak tentang hal itu dan berbagai tawaran informasi yang vulgar, dengan cara pemberian informasi tentang seksualitas yang benar, jujur, lengkap, yang disesuaikan dengan kematangan usianya. Berbicara tentang pendidikan seks tentunya tidak akan terlepas dengan pemahaman seseorang terhadap apa dan bagaimana pendidikan seks itu sendiri. Perbedaan pemahaman 
Regina L. Panjaitan, Dadan Djuanda, dan Nurdinah Hanifah, Persepsi Guru Mengenai Sex Edu...

tentang pendidikan seks ini tergantung pada bagaimana sudut pandang yang mereka gunakan dalam memberikan definisi tersebut.Mengingat pentingnya sex education diberikan pada peserta didik, dan tentunya disini guru memegang kendali dalam memfasilitasi pengembangan pembelajaran yang bermuatan sex education. Oleh karena itu penelitian ini difokuskan pada bagaimana persepsi guru terhadap sex education?

Berdasarkan latar belakang yang sudah diuraikan sebelumnya, focus penelitian ini adalah mengenai bagaimana persepsi guru terhadap sex education? Tujuan yang ingin dicapai dalam penelitian ini adalah untuk mendeskripsikan mengenai persepsi guru terhadap sex education?

\section{METODE}

Adapun tempat penelitian yang akan digunakan adalah guru sekolah dasar kelas VI di Kecamatan Tanjungsiang Kab. Subang.

\section{Metode Penelitian}

Metode yang digunakan dalam penelitian ini adalah metode penelitian deskriptif, dengan pertimbangan yang diambil dari pemaknaan definisi dari metode penelitian tersebut diantaranya yang dikemukakan oleh Sugiyono (2011) "penelitian desktiptif adalah sebuah penelitian yang bertujuan untuk memberikan atau menjabarkan suatu keadaan atau fenomena yang terjadi saat ini dengan menggunakan prosedur ilmiah untuk menjawab masalah secara aktual".Kemudian Sukmadinata (2006) menyatakan bahwa metode penelitian deskriptif adalah sebuah metode yang berusaha mendeskripsikan, menginterpretasikan sesuatu, misalnya kondisi atau hubungan yang ada, pendapat yang berkembang, proses yang sedang berlangsung, akibat atau efek yang terjadi atau tentang kecenderungan yang sedang berlangsung. Jadi Metode penelitian deskriptif merupakan salah satu metode penelitian yang banyak digunakan pada penelitian yang bertujuan untuk menjelaskan suatu kejadian.

\section{Subjek Penelitian}

Subjek Penelitian ini adalah peserta didik sekolah dasar kelas VI di Kecamatan Tanjungsiang Subang.

\section{Instrumen Penelitian}

Instrumen yang digunakan dalam penelitian ini adalah, angket, format wawancara. Angket digunakan untuk mengetahui bagaimana pandangan guru mengenai sex education yang diintegrasikan dalam proses belajar mengajar. Wawancara digunakan untuk memperoleh data untuk memperkuat data yang diperoleh melalui angket.

\section{Teknik analisis data}

Analisis statistik deskriptif adalah statistik yang digunakan untuk menganalisis data dengan cara mendeskripsikan atau menggambarkan data yang telah terkumpul sebagaimana adanya tanpa 
bermaksud membuat kesimpulan yang berlaku untuk umum atau generalisasi. Analisis ini hanya berupa akumulasi data dasar dalam bentuk deskripsi semata dalam arti tidak mencari atau menerangkan saling hubungan, menguji hipotesis, membuat ramalan, atau melakukan penarikan kesimpulan.

\section{HASIL DAN PEMBAHASAN}

Persepsi merupakan proses akhir dari pengamatan yang diawali oleh proses penginderaan, yaitu proses diterimanya stimulus oleh alat indera, kemudian individu ada perhatian, lalu diteruskan ke otak dan baru kemudian individu menyadari tentang sesuatu yang dinamakan persepsi. Dengan persepsi individu menyadari dapat mengerti tentang keadaan lingkungan yang ada disekitarnya maupun tentang hal yang ada dalam diri individu yang bersangkutan, proses mengerti tersebut didukung oleh kemampuan indera yang merupakan proses kognitif, yang dialami oleh setiap orang dalam memahami setiap informasi tentang lingkungannya baik melalui penglihatan, pendengaran, penghayatan, perasaan, dan penciuman. Pemahaman yang sama mengenai persepsi diuraikan olehWalgito (2002, p. 271), bahwa "persepsi merupakan proses psikologis dan hasil dari penginderaan serta proses terakhir dari kesadaran, sehingga membentuk proses berpikir".Selanjutnya ahli lainnya memaparkan definisi mengenai persepsi adalah Sarwono (1983, p. 89), beliau menguraikan persepsi merupakan kemampuan seseorang untuk mengorganisir suatu pengamatan, kemampuan tersebut antara lain: kemampuan untuk membedakan, kemampuan untuk mengelompokan, dan kemampuan untuk memfokuskan. Oleh karena itu seseorang bisa saja memiliki persepsi yang berbeda, walaupun objeknya sama.Terakhir definisi mengenai persepsi disebutkan oleh Mar'at (1981, p. 11) sebagai suatu proses pengamatan seseorang yang berasal dari kemampuan kognitif, menyangkut sesuatu yang dipikirkan mengenai obyek pengamatan. Persepsi merupakan apa yang dialami dengan segera oleh seseorang. Persepsi menghubungkan jalan kealam sekitar untuk mengetahui, mendengar, mencium, merasa juga membau dengan segera berdasarkan alat indra.Jadi persepsi adalah proses pemahaman ataupun pemberian makna atas suatu informasi terhadap stimulus. Stimulus sendiri didapat dari proses penginderaan terhadap objek, peristiwa, atau hubungan-hubungan antar gejala yang selanjutnya diproses oleh otak.

Lebih jauh Walgito (1991) menjelaskan mengenai syarat persepsi di atas adalah, 1) Mengenai stimulus, agar dapat dipersepsi, stimulus harus cukup kuat, melampui ambang batas, berwujud manusia atau tidak (bila tidak berwujud manusia, ketepatan persepsi ada pada individu; 2) Keadaan individu dari segi fisiologis dan psikologis, di mana dari segi fisiologis sistem syaraf harus dalam keadaan baik, sedangkan secara psikologis, pengalaman, kerangka acuan, 
Regina L. Panjaitan, Dadan Djuanda, dan Nurdinah Hanifah, Persepsi Guru Mengenai Sex Edu...

perasaan, kemampuan berpikir dan motivasi akan berpengaruh dalam persepsi seseorang, dan terakhir, 3) Lingkungan atau situasi, di mana bila objeknya manusia, maka objek dengan lingkungan yang melatar belakanginya merupakan kesatuan yang sulit dipisahkan. Demikian ini maka, dapat disimpulkan bahwa persepsi itu sangat subyektif karena disamping dipengaruhi oleh stimulus dan situasi pengamatan juga dipengaruhi oleh pengalaman, harapan, motif, kepribadian, dan keadaan fisik individu.

Proses pembentukan persepsi dimulai dengan penerimaan rangsangan dari berbagai sumber melalui panca indera yang dimiliki, setelah itu diberikan respon sesuai dengan penilaian dan pemberian arti terhadap rangsang lain. Setelah diterima rangsangan atau data yang ada diseleksi. Untuk menghemat perhatian yang digunakan rangsangan-rangsangan yang telah diterima diseleksi lagi untuk diproses pada tahapan yang lebih lanjut.Setelah diseleksi rangsangan diorganisasikan berdasarkan bentuk sesuai dengan rangsangan yang telah diterima. Setelah data diterima dan diatur, proses selanjutnya individu menafsirkan data yang diterima dengan berbagai cara. Dikatakan telah terjadi persepsi setelah data atau rangsang tersebut berhasil ditafsirkan. Sedangkan faktor-faktor fungsional yang menentukan persepsi seseorang berasal dari kebutuhan, pengalaman masa lalu, dan hal-hal lain yang dapat disebut sebagai faktor-faktor personal, yang menentukan persepsi bukan jenis atau bentuk stimuli, tetapi karakteristik orang yang memberi respon terhadap stimuli (Rakhmat, 1998). Sejalan dengan hal tersebut, maka persepsi seseorang ditentukan oleh dua faktor utama yaitu pengalaman masa lalu dan faktor pribadi (Sugiharto, 2001).

Dalam penelitian ini persepsi yang dimaksud adalah mengenai pemahaman guru tentang fenomena yang terjadi berdasarkan inderanya dalam hal ini adalah pemahaman mengenai sex education.

Jumlah instrumen penelitian yang dibagikan ada 20 eksemplar, sedangkan yang kembali untuk dianalisis ada 11 eksemplar. Adapun hasil penelitiannya adalah sebagai berikut:

Pertama, persepsi guru mengenai 'pendidikan seks sebagai sesuatu hal yang tabu' ada 6 orang guru (55\%) menyatakan bahwa pendidikan seks merupakan hal yang tabu dengan alasan di masyarakat kita pendidikan seks sangat sensitif, dan sebagai orang tua masih belum memahami pentingnya pendidikan seks selain itu sebagian anak masih polos. 5 orang guru (45\%) menyatakan pendidikan seks bukan hal yang tabu dengan alasan Anak perlu tahu tentang pendidikan seks karena pendidikan seks harus diajarkan sedini mungkin tergantung tingkatan usia anak, materi yang disampaikan berbau/tidak bisa dihindari dari sekitar alat reproduksi manusia, pendidikan seks itu 
sangat penting untuk diajarkan di kelas dan bukan merupakan suatu yang tabu di jaman yang modern ini jadi anak harus mengenal pendidikan seks sejak dini, minimal tahu.

Meninjau berbagai fenomena yang terjadi di Indonesia, agaknya masih timbul prokontra di masyarakat, lantaran adanya anggapan bahwa membicarakan seks adalah hal yang tabu dan pendidikan seks akan mendorong remaja untuk berhubungan seks. Sebagian besar masyarakat masih memandang pendidikan seks seolah sebagai suatu hal yang vulgar tapi berdasarkan sudut pandang psikologis, pendidikan seksual sangat diperlukan bagi perkembangan remaja, dengan harapan agar remaja tidak memiliki kesalahan persepsi terhadap seksualitas dan tidak terjebak pada perilaku-perilaku yang kurang bertanggungjawab.

Kedua, persepsi guru mengenai pernyataan 'saya akan malu ketika diminta untuk memberikan materi mengenai organ tubuh pada anak didik saya' ada 2 orang guru (18\%) menyatakan iya, dengan alasan Karena siswa belum mengetahui betul fungsi tersebut jika yang dimaksud alat reproduksi manusiasedangnya 9 orang guru (82\%) menyatakan tidak dengan alasan Tidak karena pemahaman tentang organ tubuh manusia poembahasannya tidak terlalu vulgar; Anak perlu tahu namanama organ tubuh dan fungsinya, termasuk alat reproduksi ; anak-anak harus mengenal organ tubuh sendiri; sangat penting memberikan materi tersebut untuk pengetahuan anak didik; anak-anak harus mengetahui bagian-bagian organ tubuh dan fungsinya; ada pembelajaran tentang masa puber pada pelajaran IPA; anak harus tahu organ tubuh mana yang tidak boleh disentuh orang lain, juga agar anak dapat memelihara organ tubuhnya dengan baik.Kemudian persepsi guru mengenai Setiap siswa yang berbicara tentang seks adalah anak nakal, ditemukan ada 2 orang guru (18\%) menyatakan iya, karena usia SD masih kekanak-kanakan; bilamana yang dibicarakan bukan mengenai kesehatan, sedangkan ada 9 orang guru (82\%) menyatakan tidak dengan alasan anak tersebut sudah terdorong masa puber; semua anak yang normal pasti membicarakan seks; anak mengetahui batasan -batasan seks; bicara tentang seks untuk pengetahuan kelas nanti; merupakan ilmu yang mereka dapatkan tentang seks agar mereka mengetahui fungsi dari organ tubuh; tergantung dari apa pokok bahasan yang anak bicarakan; anak yang ingin tahu itu lebih baik supaya tahu sisi baiknya.

Ketiga, persepsi guru mengenai 'siswa perlu pendidikan seks sehingga mereka dapat tumbuh menjadi orang dewasa yang bertanggung jawab', ada sekitar 9 orang guru (82\%) menyatakan iya dengan alasan sebab anak dengan memahami hal-hal tersebut akan tahu bahayanya pengaruh seks bebas; siswa perlu tahu kapan seks 
Regina L. Panjaitan, Dadan Djuanda, dan Nurdinah Hanifah, Persepsi Guru Mengenai Sex Edu...

dapat dilakukan dan perlu ditanamkan ke anak sejak dini; setidaknya anak yang sudah tahu pendidikan seks bisa menjaga diri sendiri; sampai pada saat dewasa terjadi kelainan seks; dengan ilmu yang mereka dapatkan akan mengerti tentang seks di kemudian hari; terbebas dari seks bebas; dewasa nanti dia tahu cara menjaga dirinya dengan baik, sedangkan ada 2 (18\%) menyatakan tidak dengan alasan karena yang diperlukan hanya mengenai bagaimana memelihara kesehatan alat reproduksi; untuk tumbuh dewasa dan bertanggungjawab bukan hanya dari pendidikan seks saja.

Keempat, persepsi guru mengenai 'pernyataan saya merasa perlu untuk memasukan kesehatan seksual pendidikan di sekolah' ada sekitar 8 orang guru (73\%) menyatakan iya dengan alasan: banyak anak-anak yang tertular penyakit akibat seks bebas; anak tidak boleh tabu tentang pendidikan seks usia dini; perlu supaya anak mengetahui sejak dini; agar anak tahu kenapa pentingnya kesehatan; siswa harus mengetahui pentingnya pendidikan kesehatan seksual itu; hal tersebut penting buat anak yang masih polos secara diri, sedangkan ada sekitar 3 orang guru $(27 \%)$ menyatakan tidak dengan alasan : karena pembelajaran harus disesuaikan dengan perkembangan anak; perlu supaya anak mengetahui sejak dini; harus dilihat porsinya.

Kelima, persepsi guru mengenai pernyataan 'saya setuju pendidikan seks harus diintegrasikan dalam pembelajaran pada setiap mata pelajaran di kelas rutin, bukan dipisah menjadi suatu mata pelajaran' ada sekitar 7 orang guru (64\%) menyatakan iya dengan alasan pendidikan seks harus diajarkan oleh guru yang memahami tentang hal itu; nanti siswa akan selalu membahas seks dalam setiap belajar; sebab anak harus sering dinasehati agar mereka ada rem bila akan melakukan hal negatif; Sedangkan 4 orang guru (56\%) menyatakan tidak dengan alasan karena pada mata pelajaran tertentu ada pelajaran seks; pendidikan seks cukup diintegrasikan dalam pendidikan agama dan IPA; mengajarkan akan lebih baik jika pendidikan seks tersebut diintegrasikan dalam IPA PKN dan oleh guru agama; nanti siswa akan selalu membahas seks dalam setiap belajar; sangat bertentangan dengan kurikulum; pada mata pelajaran tertentu materi tentang seks selalu dikaitkan.

Keenam, persepsi guru mengenai pernyataan 'pembelajaran mengenai pendidikan seks harus masuk dalam kurikulum' ada sekitar 2 orang guru (18\%) menyatakan iya dengan alasan pembelajaran jadi lebih efektif, sedangkan 9 orang guru (82\%) menyatakan tidak dengan alasan bisa disisipkan pada pelajaran tertentu; cukup pengenalan dalam pendidikan seks; cukup diintegrasikan dengan mata pelajaran yangsesuai; karena pembelajaran pendidikan seks untuk tingkatan SMP dan SMA saja; banyak hal yang lebih penting 
daripada mengenai masalah seks; pendidikan seks tersebut sudah ada dalam pelajaran IPA; sudah cukup tidak harus difokuskan mengenai pembelajaran seks.

Ketujuh, Persepsi guru mengenai 'pendidikan seks seharusnya mulai diajarkan di kelas VI SD' ada sekitar 9 orang guru (82\%) menyatakan iya, dengan alasan karena masa-masa puber; usia anak sudah memasuki fase remaja; supaya tahu sisi baik dan buruk sejak dini; perempuan sudah mulai menstruasi; pada usia tersebut anak selalu penasaran; pendidikan seks harus diajarkan mulai dari usia dini agar mereka paham, sedangkan ada 2 orang guru (18\%) menyatakan tidak, karena tidak sesuai dengan kurikulum.

Pembelajaran mengenai sex education pada intinya dikembalikan lagi kepada guru, mengingat ada beberapa hal yang memang perlu mendapat perhatian khusus. Hanya saja kita harus mengingatkan kembali bahwa Undangundang nomor 14 Tahun 2005 tentang guru dan dosen. Guru adalah pendidik profesional dengan tugas utama mendidik, mengajar, membimbing, mengarahkan, melatih, menilai dan mengevaluasi peserta didik pada pendidikan anak usia dini melalui jalur formal pendidikan dasar dan pendidikan menengah. Pengertian guru diperluas menjadi pendidik yang dibutuhkan secara dikotomis tentang pendidikan.Usman (1996, p. 15) guru adalah setiap orang yang bertugas dan berwenang dalam dunia pendidikan dan pengajaran pada lembaga pendidikan formal.Imran (2010, p. 23), guru adalah jabatan atau profesi yang memerlukan keahlian khusus dalam tugas utamanya seperti mendidik, mengajar, membimbing, mengarahkan, melatih,menilai, dan mengevaluasi peserta didik pada pendidikan anak usia dini jalur pendidikan formal, pendidikan dasar, dan menengah.

Mulyasa (2007, p. 37) mengidentifikasikan sedikitnya sembilan belas peran guru dalam pembelajaran. Kesembilan belas peran guru dalam pembelajaran yaitu, guru sebagai pendidik, pengajar, pembimbing, pelatih, penasehat, pembaharu (innovator), model dan teladan, pribadi, peneliti, pendorong kreativitas, pembangkit pandangan, pekerja rutin, pemindah kemah, pembawa cerita, aktor, emansivator, evaluator, pengawet, dan sebagai kulminator.

Mengenai Peran guru sebagai model atau contoh bagi anak. Setiap anak mengharapkan guru mereka dapat menjadi contoh atau model baginya. Oleh karena itu tingkah laku pendidik baik guru, orang tua atau tokoh-tokoh masyarakat harus sesuai dengan norma-norma yang dianut oleh masyarakat, bangsa dan negara. Karena nilai nilai dasar negara dan bangsa Indonesia adalah Pancasila, maka tingkah laku pendidik harus selalu diresapi oleh nilai-nilai Pancasila, pada posisi ini guru bisa memunculkan nilai-nilai yang ada dalam sex education. Selain itu peranan guru sebagai pengajar dan pembimbing 
Regina L. Panjaitan, Dadan Djuanda, dan Nurdinah Hanifah, Persepsi Guru Mengenai Sex Edu...

dalam pengalaman belajar, setiap guru harus memberikan pengetahuan, keterampilan dan pengalaman lain di luar fungsi sekolah seperti persiapan perkawinan dan kehidupan keluarga, hasil belajar yang berupa tingkah laku pribadi dan spiritual dan memilih pekerjaan di masyarakat, hasil belajar yang berkaitan dengan tanggung jawab sosial tingkah laku sosial anak.

\section{SIMPULAN}

Persepsi guru mengenai pendidikan seks di sekolah memperlihatkan bahwa menurut guru pendidikan seks penting mengingat jaman modern seperti sekarang diperlukan suatu materi yang bisa memberikan pemahaman kepada peserta didik mengenai materi tersebut. Walaupun penting tapi ternyata umumnya guru masih memandang bahwa pendidikan seks masih merupakan hal yang tabu untuk dibicarakan. Mengenai materinya tidak harus dipisahkan menjadi mata pelajaran yang khusus tapi cukup diintegrasikan dengan mata pelajaran tertentu yang sesuai. Para guru melihat bahwa pendidikan seks penting karena nantinya akan memberikan dasar supaya anak dapat tumbuh menjadin orang dewasa yang bertanggungjawab. Guru memiliki persepsi kalau pendidikan seks tepat dibelajarkan di kelas $\mathrm{VI}$ dengan alasan karakteristik dan kondisi psikologi anak kelas VI yang dinilai sudah memasuki masa puber.

\section{REFERENSI}

BIN. (2014). Waspadai kekerasan seksual Terhadap anak di lingkungan sekolah diakses dari http://www.bin.go.id/awas/detil/274/4/2 9/04/2014/waspadai-kekerasan-seksualterhadap-anak-di-lingkungansekolah\#sthash. mIC4ltm2.dpuf.

KPAI. (2014). Pengaduan pelecehan seksual terhadap anak melonjak. http://www.kpai.go.id/berita/pengadua n-pelecehan-seksual-terhadap-anakmelonjak/.

Mar'at. (1982). Sikap manusia perubahan serta pengukurannya. Jakarta: Ghalia. Indonesia.

Rakhmat.J. (1998). Psikologi komunikasi. Bandung: Rosda.

Sarwono.S. W. (1983). Pengantar umum psikologi. Jakartaz: Bulan Bintang.

Sugiarto, I. (2004). Mengoptimalkan daya kerja otak dengan. berfikir. Bandung: Kaifa.

Sugiyono (2011). Metode penelitian kuntitatif kualitatif dan R\&D. Bandung: Alfabeta.

Sukmadinata, N S. (2007). Metode penelitian pendidikan. Bandung: Remaja Rosdakarya.

Suwarma, A. M. (2001). Pendidikan masalah sosial budaya. Bandung: Gelar Pustaka Mandiri.

Tilaar. (2013). Pengantar pedagogik transformatif untuk indonesia. Rineka Cipta.

Undang-Undang Nomor 23 Tahun 2002 tentang Perlindungan Anak, UndangUndang Nomor 4 Tahun 1979 tentang Kesejahteraan Anak.

Walgito, B. (1991). Pengantar psikologi umum. Yogyakarta: Andi Offset. 